\title{
MIR132 Gene
}

National Cancer Institute

\section{Source}

National Cancer Institute. MIR132 Gene. NCI Thesaurus. Code C81733.

This gene is involved in the regulation of gene expression. While it has no known role in oncogenesis, MIR132 plays a role in the development of Huntington's disease. 